\title{
PELATIHAN "STRATEGI PENGELOLAAN DIRI" UNTUK MENINGKATKAN SELF CONTROL PADA REMAJA DENGAN ADIKSI GAME ONLINE TINGKAT SEDANG
}

\author{
Prida Harkina ${ }^{1}$, Rismijati E. Koesma ${ }^{2}$, Esti Wungu ${ }^{3}$ \\ 1Program Studi Psikologi FK Universitas Malahayati, Bandar Lampung. Email : prida@malahayati.ac.id \\ 2Fakultas Psikologi Universitas Padjadjaran Bandung. Email : ceu_tetty@yahoo.com.sg \\ ${ }^{3}$ Fakultas Psikologi Universitas Padjadjaran Bandung. Email : estiwungu@yahoo.com
}

\section{ABSTRACT: "SELF MANAGEMENT STRATEGY" TRAINING TO IMPROVE SELF-CONTROL IN ADOLESCENCE WITH MODERATE LEVEL ONLINE GAME ADDICTION}

Introduction: These days, online game addiction phenomenon has increased, especially among middle school adolescences. Therefore, a prevential treatment is needed to avoid their addiction getting worse. One of the way is by strengthening adolescence' self-control in playing online game.

Purpose: The aim of this study was to determine the effect of "Self Management Strategy" training to improve selfcontrol in adolescences with moderate level online game addiction.

Methods: This study used quasi experiment with A-B-A reversal design. The intervention was done by giving training that used behavior modification basic principle. Measurementof self-control was done in every phase $A$ (when there are no treatment) and $B$ (when treatment was given).

Results: According to the data obtained, there was an improvement found in self-control score in two respondents before and during the treatment given.

Conclusion:Self management strategy training can improve self control in adolescence with moderate level online game addiction.

\section{Keywords: online game addiction, self-control, behavior modification, self management strategy}

Pendahuluan: Fenomena kasus adiksi game online saat ini marak terjadi pada pemain remaja Sekolah Menengah Pertama. Oleh karena itudibutuhkan suatu penanganan pencegahan agar adiksi yang mereka alami tidak semakin memburuk. Salah satu caranyaadalah dengan memperkuat self-control pada remaja saat bermain game online

Tujuan: Penelitian ini bertujuan untuk melihat pengaruh pelatihan "Strategi Pengelolaan Diri" untuk meningkatkan self-control pada remaja dengan adiksi game online tingkat sedang.

Metode: Penelitian ini merupakan penelitian quasi eksperimen dan menggunakan A-B-A reversal design. Intervensi yang dilakukan berbentuk pelatihan dengan menggunakan prinsip dasar behavior modification. Pengukuran terhadap self-control dilakukan di setiap fase A (saat tidak ada treatment) dan B (saat diberikan treatment)

Hasil: Berdasarkan data yang diperoleh selama pengukuran menunjukkan bahwa terjadi peningkatan jumlah skor self-control pada kedua peserta dari saat belum diberikan treatmant ke pada saat treatment diberikan.

Simpulan: Pelatihan Strategi Pengelolaan Diri dapat meningkatkan self-control (kontrol diri) pada remaja dengan adiksi game online tingkat sedang.

\section{Kata kunci: adiksi game online, self-control, behavior modification, strategi pengelolaan diri}

\section{PENDAHULUAN}

Game online adalah permainan komputer yang dapat dimainkan oleh lebih dari satu pemain melalui sambungan internet. Dengan demikian, para pemain tidak harus berada dalam satu tempat tertentu dan tetap dapat memainkan permainan ini dari depan layar komputer mereka masing-masing, selama mereka tersambung melalui layanan internet. Selain itu, mereka juga tidak harus saling bertatap muka langsung, serta tetap dapat menjaga sifat "anonim" antara satu sama lain, selama permainan berlangsung (Sanditaria, 2012).

Ada beberapa faktor yang membuat permainan game online menjadi permainan yang dapat menarik perhatian dan minat para pemainnya. Permainan ini biasanya dirancang dengan tampilan yang menarik, termasuk setiap gerakan, warna, juga suara yang bersifat menghibur. Selain itu, permainan dalam game online memiliki cara bermain dan aturan permainannya sendiri, serta biasanya melibatkan tema petualangan, pengaturan strategi, stimulasi, dan bermain peran. Keunikan cara bermain dan 
penyelesaian masalah, yang berbeda-beda di setiap tingkatannya menjadi sesuatu yang menantang bagi para pemainnya. Bahkan dalam permainan game online, sebenarnya pemain tidak akan pernah menemukan kata "selesai" karena game online memang dirancang dengan tingkatan yang terus berkembang sehingga pemain tidak akan benarbenar dapat menuntaskan permainan(Griffiths, 2008).

Satu faktor lain yang menjadikan permainan game online menjadi permainan yang diminati oleh para pemainnya adalah karena terciptanya suatu dunia virtual dalam permainan game online. Dalam dunia virtual tersebut, pemain diberi kesempatan untuk mengkreasikan lingkungan seperti apa yang ingin mereka masuki dalam permainan. Selain itu, pemain juga dapat "menciptakan" versi virtual dari diri mereka sendiri. Pemain dapat menentukan jenis kelamin, warna kulit, warna mata, warna dan jenis rambut, ras, pekerjaan, bahkan kemampuan yang dimiliki. Dalam kata lain, di dunia game online, pemain diberi kesempatan untuk menentukan diri mereka sendiri, sesuai dengan keinginan masingmasing. Hal ini adalah salah satu alasan mengapa para pemain game online memiliki perasaan keterlibatan yang kuat saat mereka sedang bermain game online. (Taylor, 2009; Jones, 2003)

Dalam banyak penelitian yang telah dilakukan, ditemukan bahwa permainan game online dapat menimbulkan ketertarikan yang tinggi pada para pemainnya sehingga menimbulkan keinginan untuk terus-menerus mengulangi kegiatan bermain game online. Kondisi ini adalah kondisi yang biasanya menjadi awal terjadinya tingkah laku adiksi atau kecanduan pada permainan game online. Para pemain yang berada pada tahap awal dari rangkaian terjadinya perilaku adiksi, perilaku mereka mengulangi kegiatan bermain game online adalah untuk memenuhi perasaan senang yang mereka rasakan saat mereka bermain permainan game online (Freimuth, 2008).

Perasaan senang yang kuat dirasakan oleh para pemain game onlne saat mereka sedang bermain game online, adalah salah satu bentuk simptom kriteria perilaku adiksi yang perlu dicermati, yaitu euphoria. Pemain merasakan perasaan senang dan nyaman saat bermain game online, serta merasa terlibat atau "masuk" ke dalam permainan. Situasi "senang" ini kemudian menjadi salah satu reinforcement (penguat) internal bagi para pemain untuk mengulangi perilaku bermain game online mereka secara berulang-ulang, tidak terkecuali pada anak-anak (Clark, 2006; West \&Brown, 2013).

Selain reinforcement internal tersebut, pada remaja yang bermain game online, terdapat pula reinforcement eksternal yangdapat menjadi penguat mereka untuk mengulangi perilaku bermain game online, yaitumudahnya akses bermain game online melaluiwarnet khusus game onlinesertakurangnya pengawasan dari orang tua. Keberadaan warnet game online, yang masih berada di sekitar lingkungan rumah anak justru membuat orang tua merasa tidak khawatir akan dimana keberadaan anak selama mereka bekerja di siang hari ataupun di hari-hari libur. Banyak orang tua yang justru merasa terbantu dan menganggap bahwa dengan berada di warnet game online, anak jadi tidak bermain ke tempat-tempat lain yang tidak mereka ketahui dimana keberadaannya.

Reinforcements yang diterima remaja, baik dari dalam diri (internal) maupun dari lingkungan luar (eksternal), ini kemudian menjadi penguat bagi anak untuk mengulangi perilaku bermain game online. Mereka menghabiskan sebagian besar waktu mereka di warnet game online untuk bermain game online; merencanakan waktu bermain mereka, namun tidak menepati waktu bermain seperti yang direncanakan; memilih untuk bermain game online dibandingkan melakukan aktivitas lain yang harus dikerjakan (seperti belajar, mengerjakan tugas, tidur, makan), sehingga durasi waktu permainan mereka juga semakin meningkat dari sejak pertama kali mereka bermain game online. Selain itu, para remaja ini juga mulai merasakan perasaan tidak nyaman (gelisah) jika tidak bermain game online hingga menimbulkan keinginan untuk kembali bermain.

Ada enam simptom yang dapat digunakan sebagai kriteria penentu munculnya perilaku adiksi, yaitu salience, euphoria, withdrawal, conflict, tolerance, dan relapes and reinstatement. Ke-enam simptom kriteria tersebut harus muncul dalam tingkat yang tinggi untuk seseorang dapat dikatakan sudah mengalami kecanduan suatu perilaku tertentu. Selain itu, dari enam simptom kriteria tersebut, ada satu simptom kriteria yang dapat membedakan apakah perilaku seseorang sudah dapat dikategorikan sebagai tingkah laku adiksi ataukah masih dapat dikategorikan sebagai tingkah laku high engagement dalam konteks permainan game online. Simptom tersebut adalah simptom withdrawal (Charlton dan Danforth, 2007; West \& Brown, 2013).

Dalam kata lain, seseorang dapat saja menghabiskan banyak waktu dalam bermain game

\footnotetext{
1 PridaHarkina Program Studi Psikologi FK Universitas Malahayati, Bandar Lampung. Email : prida@malahayati.ac.id

${ }^{2}$ Rismijati E. Koesma Fakultas Psikologi Universitas Padjadjaran Bandung. Email : ceu tetty@yahoo.com.sg

${ }^{3}$ EstiWungu Fakultas Psikologi Universitas Padjadjaran Bandung. Email : estiwungu@yahoo.com
} 
online dan merasakan perasaan senang dan keterlibatan yang tinggi saat bermain game online, namun tidak merasa cemas/gelisah saat tidak bermain game online. Namun saat individu merasakan perasaan cemas/gelisah saat mereka tidak melakukan kegiatan bermain game online (withdrawal), hal ini akan menjadi pemicu mereka untuk kembali mengulangi perilaku bermain game online, hingga perilaku akan ini terus menerus diulangi dan dapat menjadi perilaku adiksi (ketergantungan)(Charlton dan Danforth, 2007; Ningtyas 2012; West \& Brown, 2013).

Berdasarkan pada perilaku yang ditampilkan oleh para remaja dalam bermain game online, terlihat bahwa beberapa perilaku tersebut mulai menunjukkan adanya simptom yang menjadi kriteria terjadinya perilaku adiksi. Di antaranya adalah : a) simptom salience, yang ditunjukkan dengan kegiatan bermain game online telah menjadi salah satu kegiatan yang mendominasi pikiran dan waktu dalam kehidupan remaja sehari-sehari; b) simptom euphoria, yang ditunjukkan dengan adanya perasaan keterlibatan dan perasan senang yang kuat dirasakan remaja saat bermain game online, yang membuat mereka memilih untuk menghabiskan banyak waktu untuk bermain game online meskipun mereka tahu kalau ada kegiatan lain yang harus mereka lakukan; serta c) simptom tolerance, yang ditunjukkan dengan adanya peningkatan durasi waktu permainan mereka dari sejak pertama kali mereka bermain game online. Selain ke-tiga simptom tersebut, para remaja ini juga sudah menunjukkan munculnya simptom withdrawal, sebagai simptom yang menentukan apakah suatu perilaku sudah dapat dikategorikan sebagai tingkah laku adiksi ataukah belum. Simptom withdrawal ini terlihat dari adanya perasaan tidak nyaman (gelisah) jika mereka tidak bermain game online. Menurut mereka, hal ini juga menjadi salah satu alasan yang memicu munculnya keinginan untuk terus-menerus bermain game online, yaitu untuk mengurangi perasaan gelisah tersebut.

Meskipun belum dapat dikategorikan mengalami tahapan adiksi tingkat tinggi bermain game online karena tidak semua simptom kriteria adiksi muncul dalam tingkat tinggi, namun perilaku yang ditunjukkan oleh para remaja pemain game online itu telah memperlihatkan adanya simptom kriteria penentu tingkah laku adiksi. Dapat dikatakan bahwa saat ini, para remaja pemain game online tersebut mengalami adiksi game online tingkat sedang.
Selain itu, perilaku yang ditunjukkan oleh para remaja pemain game online ini menunjukkan adanya self-control yang menurun, yang merupakan pola awal terjadinya suatu perilaku adiksi penuh. Dalam kata lain, meskipun belum dapat dikategorikan sebagai perilaku adiksi penuh, namun jika tidak dilakukan suatu bentuk pencegahan (tindakan preventif), perilaku bermain game online ini dapat mengarah para perilaku out of control (tidak terkendali) atau disebut juga tahap adiksi penuh(Goodman, 1990; O'Donoghue\& Rabin, 1999).

Pada anak-anak yang bermain game online, bentuk tindakan preventif yang dapat dilakukan untuk mencegah perilaku bermain game online mereka saat ini menjadi suatu perilaku yang sepenuhnya adiksi adalah dengan memperkuat self-control remaja saat ini.

Self-control adalah kemampuan untuk membimbing tingkah laku sendiri, kemampuan untuk menekan, merintangi impuls-impuls atau tingkah laku impulsif. Self-control merupakan suatu mekanisme yang dapat membantu mengatur dan mengarahkan perilaku, sehingga dengan memperkuat self-control remaja, diharapkan remaja dapat mengarahkan tingkah lakunya saat bermain game online dengan lebih baik, serta meningkatkan kemampuan pengelolaan diri mereka(O'Donoghue\& Rabin, 1999; Chaplin, 2006).

Satu cara yang dapat dilakukan untuk menguatkan self-control pada remaja yang mengalami adiksi game online tingkat sedang, adalah dengan melakukan perubahan perilaku mereka, dari perilaku tidak dapat mengarahkan diri dengan baik saat bermain game online menjadi perilaku yang lebih disiplin.Perubahan perilaku ini dapat dilakukan dengan mengajarkan suatu pelatihan strategi pengelolaan diri, yang menerapkan prinsip dari teori behavior modification. Prinsip-prinsip tersebut, antara lain : a) memunculkan kesadaran pada remaja mengenai pentingnya perubahan perilaku yang harus mereka lakukan; b) membantu para remaja menentukan tingkah laku mana yang ingin diubah, dimana tingkah laku tersebut harus dapat terukur dengan baik, c) membentuk goal setting (target perubahan tingkah laku), yang dapat dicapai; d) mengubah setting/kejadian sebelumnya untuk mencegah perilaku yang ingin diubah kembali terjadi; e) melakukan pencatatan akurat terhadap keberhasilan dan kegagalan target perilaku; dan f) membangun rencana untuk memberi reward pada diri sendiri saat berhasil memenuhi goal (Cormier \&

\footnotetext{
1 PridaHarkina Program Studi Psikologi FK Universitas Malahayati, Bandar Lampung. Email : prida@malahayati.ac.id

${ }^{2}$ Rismijati E. Koesma Fakultas Psikologi Universitas Padjadjaran Bandung. Email : ceu tetty@yahoo.com.sg

${ }^{3}$ EstiWungu Fakultas Psikologi Universitas Padjadjaran Bandung. Email : estiwungu@yahoo.com
} 
Cormier, 1987; Young, 2007; Miltenberger, 2011; Sarafino, 2012).

Dalam penelitian ini, prinsip-prinsip behavior modificationtersebut akan diterapkan pada tiga strategi, yang merupakan bagian dari pelatihan strategi pengelolaan diri. Pada tahap awal pelatihan, akan dilakukan pemberian insight pada para remaja tersebut dengan tujuan memunculkan kesadaran pada remaja mengenai pentingnya perubahan perilaku yang harus mereka lakukan dalam kegiatan bermain game online. Setelah itu, mereka akan diajarkan mengenai tiga strategi dalam pelatihan strategi pengelolaan diri. Ketiga strategi tersebut adalah : (1) strategi self-monitoring; (2) strategi stimulus control; dan (3) strategi self-reward (Cormier \& Cormier, 1987; Miltenberger, 2011).

Dalam pelatihan strategi self-monitoring, prinsip behavior modification yang diterapkan adalah menentukan perubahan perilaku dan menentukan goal setting yang dapat dicapai. Dalam penerapannya, remaja akan diminta untuk menentukan sebuah target perubahan perilaku, yaitu : mengurangi durasi waktu bermain game online mereka sehari-hari. Setelah itu, para remaja tersebut diminta untuk menentukan goal yang dapat dicapai, yaitu : target durasi waktu bermain game online, yang akan mereka latihkan dalam sebuah sesi latihan mandiri (dalam setting kehidupan sehari-hari). Keberhasilan/kegagalan remaja dalam memenuhi target durasi waktu bermain game online pada latihan mandiri akan dicatat dan didiskusikan bersama.

Dalam pelatihan strategi stimulus control, prinsip behavior modification yang akan diterapkan adalah usaha untuk memodifikasi kejadian sebelumnya yang dapat mencegah individu mencapai goal-nya. Usaha ini dilakukan melalui diskusi mengenai hal-hal apa saja yang dapat menghambat para remaja tersebut dalam mencapai goal (berupa target durasi waktu bermain game online, yang disepakati sebelumnya) dan alternatif cara yang dapat mereka lakukan untuk mengatasi hambatan tersebut. Hasil diskusi tersebut kemudian akan diaplikasikan oleh para peserta dalam kehidupan sehari-hari, melalui latihan mandiri.

Dalam pelatihan strategi self-reward, prinsip behavior modification yang akan diterapkan adalah adanya usaha untuk membangun rencana untuk memberikan reward pada diri sendiri saat berhasil memenuhi "goal" sehari-hari dan rencana memberikan hukuman saat gagal. Dalam penerapannya, penggunaan strategi self-reward tidak dengan pemberian hukuman saat para remaja gagal memenuhi target waktu bermain game online, namundengan menggunakan pemberian memberikan reward pada diri sendiri saat berhasil memenuhi target waktu bermain game online yang telah ditentukan. Hal ini dilakukan untuk membantu klien mengatur dan menguatkan tingkah laku mereka sesuai konsekuensi yang telah ditetapkan (Cormier \& Cormier, 1987; Miltenberger, 2011).

Self-monitoring, stimulus control, dan selfreward adalah tiga strategi dalam strategi pengelolaan diri yang diharapkan dapat melatih remaja untuk merubah perilaku bermain game online mereka yang berlebihan, sehingga juga akan dapat meningkatkan kemampuan mereka dalam mengontrol dan mengurangi kebiasaan bermain game online yang berlebihan. Selain itu, dengan pelatihan ini remaja juga diharapkan lebih dapat mengelola diri mereka dengan lebih baik lagi ke depannya.

\section{METODE PENELITIAN}

Penelitian ini dilakukan dengan menggunakan rancangan quasi experiment. Desain penelitian yang digunakan dalam penelitian ini adalah $A-B-A$ Reversal Designs, yaitu desain penelitian yang memfokuskan untuk melihat perubahan tingkah laku dari subjek melalui serangkaian pengukuran saat subjek tidak mendapatkan treatment dan saat mendapatkan treatment. Dengan demikian, pada desain ini diperlukan pengukuran berulang kali sehingga perubahan yang mungkin terjadi dapat termonitor. Pada rancangan ini, subjek akan melalui 3 fase atau tahap penelitian yaitu $A$ (pengukuran saat tidak ada pemberian treatment), $\mathrm{B}$ (treatment), dam A kembali (pengukuran saat tidak ada treatement). Dalam rancangan ini, pengaruh pemberian treatment tersebut dapat dilihat dengan membanding-kan hasil pengukuran saat subjek tidak mendapatkan treatment dan saat mendapatkan treatment (Todman \& Dugard, 2001; Fife-Schaw, 2012).

Subyek penelitian adalah dua remaja berusia 12-14 tahun (Sekolah Menengah Pertama), yang mengalami adiksi bermain game online tingkat sedang.Pada penelitian sampel diambil ini menggunakan teknik purposive sampling.

Penelitian ini menggunakankuesioner "Adiksi Game Online pada Remaja" yang dibuat berdasarkan kriteria tingkah laku adiksi dari J. Brown. Tujuannya untuk mengidentifikasi-kan remaja yang mengalami adiksi game online tingkat sedang, beserta aspekaspek adiksi yang mempengaruhi perilaku yang

\footnotetext{
1 PridaHarkina Program Studi Psikologi FK Universitas Malahayati, Bandar Lampung. Email : prida@malahayati.ac.id

${ }^{2}$ Rismijati E. Koesma Fakultas Psikologi Universitas Padjadjaran Bandung. Email : ceu tetty@yahoo.com.sg

${ }^{3}$ EstiWungu Fakultas Psikologi Universitas Padjadjaran Bandung. Email : estiwungu@yahoo.com
} 
ditampilkan anak, berkaitan dengan kegiatan bermain game online. Kuesioner ini terdiri dari 45 item, dan mengukur enam kategori manifestasi simptomsimptom spesifik adiksi, yaitu salience, euphoria, conflict, tolerance, withdrawal, serta relapse and reinstatement(Clark, 2006; West \& Brown, 2013).

Kuesioner kedua yang digunakan dalam penelitian ini adalah kuesioner "Self Control bermain game online"yang dibuat berdasarkan konsep yang diturunkan dari teori self control personal. Kuesioner ini terdiri dari 30 item, mengenai kemampuan subjek dalam mengendalikan pikiran (cognitive), keputusan (decisional), dan tingkah lakunya (behavioral) dalam bermain game online, yang merupakan tiga dimensi dari self-control personal. Selain itu, dalam penelitian ini juga digunakan lembar catatan untuk mencatat durasi waktu dan perilaku perilaku yang ditampilkan anak selama bermain game online remaja, setiap hari selama penelitian berlangsung (fase $A$ dan fase B)(Averill, 1973).

\section{Pelaksaanaan Pelatihan}

Pelatihan dilakukan selama sepuluh hari, dengan empat kali pertemuan tatap muka dan enam hari latihan mandiri. Pertemuan pertama diisi dengan materi, sharing pengalaman, insight, serta goal setting danpembelajaran cara mencapai goal. Kemudian disepakati waktu 2 hari bagi peserta untuk melatih materi strategi pengelolaan diri yang telah diberikan pada pertemuan pertama, secara mandiri dalam situasi langsung di kehidupan sehari-hari. Pertemuan kedua dimulai dengan melakukan pengukuran $\mathrm{Ob}_{1}$ (pengukuran pertama selama treatment diberikan), dan dilanjutkan dengan berbagi pengalaman selama peserta melakukan latihan mandiri di luar pertemuan, serta hambatan apa yang dihadapi. Kemudian peserta membuat goal setting baru, yang lebih sulit dari sebelumnya, untuk latihan mandiri berikutnya, beserta cara yang dapat dilakukan untuk mencapai goal tersebut. Setelah itu, kembali disepakati waktu 2 hari untuk melakukan latihan mandiri, dengan goal yang baru. Pada pertemuan ketiga, kembali dilakukan pengukuran $\mathrm{Ob}_{2}$ (pengukuran kedua selama treatment diberikan), dan dilanjutkan dengan berbagi pengalaman selama peserta melakukan latihan mandiri kedua. Kemudian peserta membuat goal setting baru, yang mereka rasa lebih sesuai untuk mereka saat ini, untuk latihan mandiri berikutnya, beserta cara yang dapat dilakukan untuk mencapai goal tersebut, sesuai dengan pengalaman dari latihan mandiri sebelumnya.
Setelah itu, kembali disepakati waktu 2 hari untuk melakukan latihan mandiri, dengan goal yang baru. Pada pertemuan keempat, dilakukan pengukuran $\mathrm{Ob}_{3}$ (pengukuran ketiga selama treatment diberikan), serta diisi dengan review dari pertemuan pertama, hingga ke evaluasi.

\section{Analisis Data}

Data kuantitatif dilihat dengan menghitung hasil pengukuran di setiap fase, baik di fase $\mathrm{A}\left(\mathrm{Oa}_{1}-\mathrm{Oa}_{3}\right)$, maupun di fase $\mathrm{B}\left(\mathrm{Ob}_{1}-\mathrm{Ob}_{3}\right)$ dengan cara setiap item dihitung berdasarkan skor dari setiap pilihan jawaban yang dipilih. Kemudian didapatkan skor dan disesuaikan dengan kategorisasi tingkat self-control yang sudah ditentukan.Sementara data kualitatifdihitung dengan mengolah data yang didapatkan dari hasil kegiatan pelatihan strategi pengelolaan diri, seperti ungkapan-ungkapan yang muncul selama diskusi berlangsung, catatan keberhasilan peserta dalam memenuhi target waktu bermain, catatan pelaksanaan latihan mandiri, sebagai indikator bahwa subjek telah mendapatkan insight untuk merubah perilaku bermain game online, yang berlebihan.

\section{HASIL \\ Pengolahan Skor Self-Control}

Perhitungan hasil pengukuran di setiap fase dilakukan untuk melihat apakah ada atau tidak ada peranan pemberian pelatihan "Strategi Pengelolaan Diri" terhadap peningkatan self-control pada remaja dengan adiksi game online tingkat sedang. Penelitian ini menggunakan model desain penelitian $A-B-A$ Reversal Design, dimana fase $A$ adalah fase saat tidak ada pemberian treatment (baseline) dan fase $B$ adalah fase saat pemberian treatment. Perhitungan terhadap hasil pengukuran dilakukan dengan membandingkan rata-rata total skor "Self-Control" dari sebelum diberikan treatment (fase $A_{1}$ ) dan saat pemberian treatment (fase B). Berdasarkan perbandingan hasil rata-rata total skor "self-control" pada fase $A_{1}$ (sebelum diberikan treatment), fase $B$ (selama diberikan treatment), dan fase $A_{2}$ (setelah diberikan treatment), didapatkan hasil bahwa hasil rata-rata skor total "self-control" pada fase sebelum diberikan treatment (Fase $\left.A_{1}\right)<$ fase pemberian treatment (Fase $B$ ) < fase seetelah diberikan treatment (Fase $\mathrm{A}_{2}$ ). Dalam kata lain, dapat dikatakan bahwa pelatihan "Strategi Pengelolaan Diri" dapat meningkatkan self-control pada remaja dengan adiksi game online tingkat sedang.

\footnotetext{
1 PridaHarkina Program Studi Psikologi FK Universitas Malahayati, Bandar Lampung. Email : prida@malahayati.ac.id

${ }^{2}$ Rismijati E. Koesma Fakultas Psikologi Universitas Padjadjaran Bandung. Email : ceu tetty@yahoo.com.sg

${ }^{3}$ EstiWungu Fakultas Psikologi Universitas Padjadjaran Bandung. Email : estiwungu@yahoo.com
} 


\section{Grafik 1. Pengolahan Skor Cognitive Control}

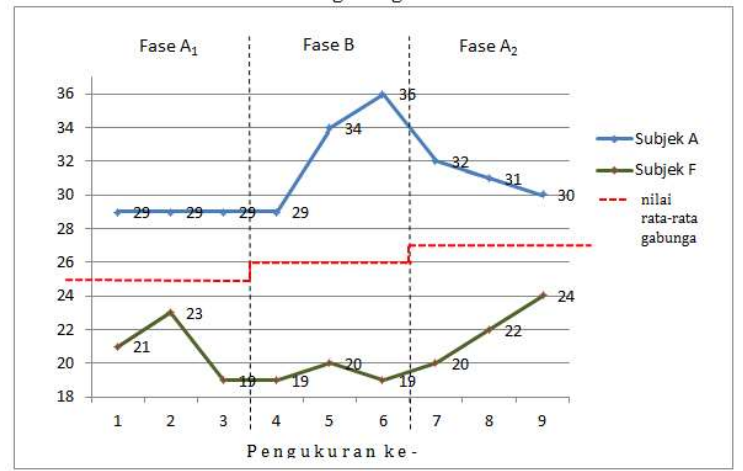

Berdasarkan grafik 1 , didapatkan suatu pola grafik mengenai nilai rata-rata cognitive-control kedua peserta saat sebelum mendapatkan latihan "Strategi Pengelolaan Diri" (fase $A_{1}$ ), selama mendapatkan latihan "Strategi Pengelolaan Diri" (fase B), serta setelah mendapatkan latihan "Strategi Pengelolaan Diri" (fase $A_{2}$ ). Pola grafik yang tercipta, yaitu : terbentuk grafik menanjak dari fase $A_{1}$ (sebelum mendapatkan pelatihan) menuju ke fase $B$ (selama mendapatkan pelatihan), lalu kembali sedikit menanjak saat di fase $\mathrm{A}_{2}$ (setelah mendapatkan pelatihan).

\section{Grafik 2. Pengolahan Skor Decisional Control}

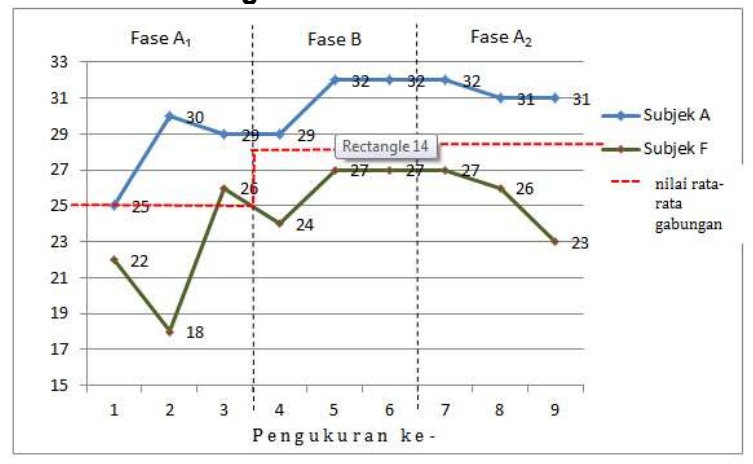

Berdasarkan grafik 2, didapatkan suatu pola grafik mengenai nilai rata-rata decision-control kedua peserta saat sebelum mendapatkan latihan "Strategi Pengelolaan Diri" (fase $A_{1}$ ), selama mendapatkan latihan "Strategi Pengelolaan Diri" (fase B), serta setelah mendapatkan latihan "Strategi Pengelolaan Diri" (fase $A_{2}$ ). Pola grafik yang tercipta, yaitu : terbentuk grafik menanjak dari fase $A_{1}$ (sebelum mendapatkan pelatihan) menuju ke fase $B$ (selama mendapatkan pelatihan), lalu kembali sedikit menanjak saat di fase $A_{2}$ (setelah mendapatkan pelatihan). Hal ini berarti dapat dikatakan bahwa kemampuan mengambil keputusan dalam membatasi kegiatan bermain game online pada remaja dengan adiksi game online tingkat sedang mengalami peningkatan setelah mendapatkan pelatihan strategi pengelolaan diri.

\footnotetext{
1 PridaHarkina Program Studi Psikologi FK Universitas Malahayati, Bandar Lampung. Email : prida@malahayati.ac.id

2 Rismijati E. Koesma Fakultas Psikologi Universitas Padjadjaran Bandung. Email : ceu_tetty@yahoo.com.sg

${ }^{3}$ EstiWungu Fakultas Psikologi Universitas Padjadjaran Bandung. Email : estiwungu@yahoo.com
} 


\section{Grafik 3. Pengolahan Skor Behavior Control}

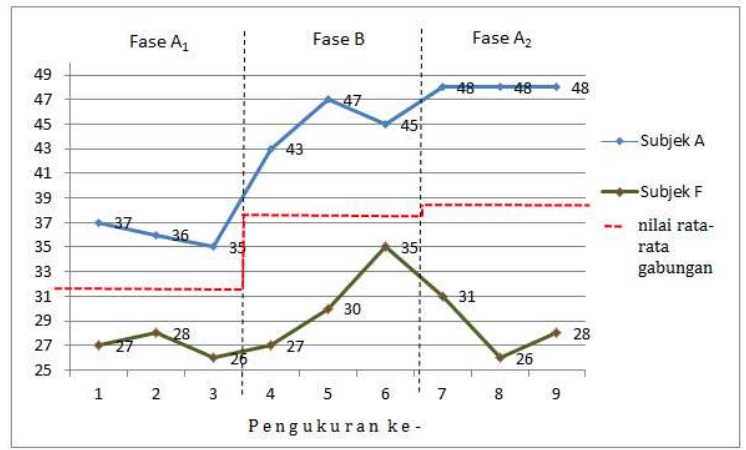

Berdasarkan grafik 3, didapatkan suatu pola grafik mengenai nilai rata-rata behavior-control kedua peserta saat sebelum mendapatkan latihan "Strategi Pengelolaan Diri" (fase $A_{1}$ ), selama mendapatkan latihan "Strategi Pengelolaan Diri" (fase B), serta setelah mendapatkan latihan "Strategi Pengelolaan Diri" (fase $A_{2}$ ). Pola grafik yang tercipta, yaitu : terbentuk grafik menanjak dari fase $A_{1}$ (sebelum mendapatkan pelatihan) menuju ke fase $B$ (selama mendapatkan pelatihan), lalu kembali sedikit menanjak saat di fase $A_{2}$ (setelah mendapatkan pelatihan). Hal ini berarti dapat dikatakan bahwa kemampuan mengendalikan tingkah laku bermain game online dan memodifikasi stimulus berupa bermain game online pada remaja dengan adiksi game online tingkat sedang mengalami peningkatan setelah mendapatkan pelatihan strategi pengelolaan diri.

\section{Kesimpulan Hasil Skor Self-Control}

Pelatihan strategi pengelolaan diri dapat meningkatkan self control bermain game online pada remaja dengan adiksi game online tingkat sedang, dengan meningkatkan ketiga aspek dari self control, yaitu cognitive control, decision control, dan behavior control.

Gambaran Keberhasilan Peserta dalam Menjalankan Pelatihan "Strategi Pengelolaan Diri"

Pelatihan "Strategi Pengelolaan Diri" dilakukan selama sepuluh hari berturut-turut, yang terdiri dari : empat hari pertemuan tatap muka dan enam hari latihan mandiri. Latihan mandiri dilakukan sebanyak 3 kali, masing- masing selama dua hari, diselingi setiap 1 kali pertemuan tatap muka. Dalam latihan mandiri, peserta diminta untuk membatasi waktu bermain game online mereka, sesuai dengan target waktu bermain game online, yang sudah mereka sepakati sebelumnya. Selain itu, peserta juga diminta untuk mempraktekan apa yang sudah didiskusikan dalam pertemuan tatap muka sebelumnya, agar mereka dapat memenuhi target waktu bermain game online dalam kehidupan sehari-hari.

Gambaran keberhasilan peserta dalam menjalankan target waktu bermain game online selama latihan mandiri Pelatihan "Strategi Pengelolaan Diri", dapat dilihat berikut :

Tabel 1. Catatan Keberhasilan Peserta dalam Menjalankan Target Waktu Bermain Game Online selama Pelatihan "Strategi Pengelolaan Diri"

\begin{tabular}{lllllll}
\hline \multirow{2}{*}{ Subjek } & \multicolumn{2}{l}{ Latihan 1 } & \multicolumn{2}{l}{ Latihan 2 } & \multicolumn{2}{l}{ Latihan 3 } \\
& \multicolumn{2}{l}{ (3-4 jam/hari) } & \multicolumn{2}{l}{ (0-1 jam/hari) } & \multicolumn{2}{l}{ (0-3 jam/hari) } \\
& Hari 1 & Hari 2 & Hari 1 & Hari 2 & Hari 1 & Hari 2 \\
\hline A & 3,5 jam & 4,5 jam & 1 jam & 0 jam & 0 jam & 3 jam \\
F & 3 jam & 4 jam & 0 jam & 0 jam & 0 jam & 1 jam \\
\hline
\end{tabular}

\section{DISKUSI}

Berdasarkan pada hasil pengujian hipotesis terhadap data yang diperoleh, pelatihan strategi pengelolaan diri dapat meningkatkan self control bermain game online pada remaja dengan adiksi game online tingkat sedang. Pelatihan "Strategi Pengelolaan Diri" efektif karena menggunakan penerapan teori behavior modification, dengan dua pendekatan : a) Pendekatan cognitive behavior, yang digunakan untuk menumbuhkan insight pada peserta, terkait dengan kondisi tingkat adiksi game online; dan b) Pendekatan self-management, sebagai dasar latihan perubahan perilaku bermain game online.

\footnotetext{
1 PridaHarkina Program Studi Psikologi FK Universitas Malahayati, Bandar Lampung. Email : prida@malahayati.ac.id

${ }^{2}$ Rismijati E. Koesma Fakultas Psikologi Universitas Padjadjaran Bandung. Email : ceu_tetty@yahoo.com.sg

3 EstiWungu Fakultas Psikologi Universitas Padjadjaran Bandung. Email : estiwungu@yahoo.com
} 
Asumsi dasar dari pendekatan cognitive behavior adalah adanya proses kognisi yang menjadi mediasi bagi perilaku, pengalaman, dan perubahan perilaku yang diharapkan. Aspek kognisi dianggap memiliki peranan penting, terutama dalam mempertim-bangkan berbagai perilaku yang hendak dilakukan, menentukan pilihan-pilihan terhadap perilaku tersebut, dan mengambil keputusan terhadap perilakunya. Sehingga fokus pada pendekatan cognitve behavior adalah pada perubahan cara berpikir keliru yang kemudian menghasilkan latihan perubahan perilaku (Cao, Su, \& Gao, 1991; Corey, 2012).

Oleh karena itu, pelatihan ini diawali dengan menumbuhkan insight pada para peserta mengenai kondisi adiksi bermain game online mereka. Insight ini ditumbuhkan melalui pemberian informasi mengenai tahapan adiksi game online beserta gejala perilaku yang ditampilkan pada setiap tahapannya. Dalam pelaksanaannya, kedua peserta mendapatkan insight setelah mengenali gejala perilaku adiksi game online tingkat sedang (atau tahap "beresiko" pada pelaksanaan pelatihan) sebagai perilaku yang juga mereka tampilkan, terkait dengan kegiatan bermain game online mereka sehari-hari. Hal ini terlihat dari jawaban yang diberikan oleh subyek penelitian, yang langsung menjawab kalau mereka menduga posisi mereka berada pada tingkat sedang (tahap "beresiko"), saat peneliti menanyakan pendapat mereka mengenai posisi tingkat adiksi bermain game online mereka saat ini, jika didasarkan pada gejala perilaku adiksi game onlinedi setiap tahapannya. Kegiatan menghitung jumlah skor kuesioner "Adiksi Game Online", yang kemudian disesuaikan dengan kategorisasi tingkat adiksi bermain game onlineadalah cara yang dilakukan untuk membuktikan dugaan kedua peserta mengenai posisi tingkat adiksi bermain game online mereka saat ini. Hal ini dilakukan untuk memperkuat insight yang didapatkan kedua peserta sebelumnya (Freimuth, 2008; West \& Brown, 2013).

Munculnya insight menunjukkan adanya kesadaran pada kedua peserta mengenai cara berpikir mereka yang selama ini keliru, terkait dengan kegiatan bermain game online mereka selama ini. Hal ini terlihat pada jawaban subjek $A$, yang mengatakan bahwa setelah diberikan informasi mengenai adiksi bermain game online serta tahapan adiksi bermain game online, A menjadi terpikir bagaimana jika $\mathrm{A}$ yang sampai pada tahap adiksi bermain game online tingkat tinggi. Menurut $A$, informasi ini menumbuhkan kesadaran A mengenai kegiatannya bermain game online, padahal sebelumnya, dia tidak pernah memikirkannya. Baik $A$ dan $F$ kemudian sepakat bahwa dibutuhkan adanya suatu perubahan perilaku untuk mencegah agar mereka tidak sampai ke tahap adiksi bermain game online tingkat tinggi.

Pelatihan Strategi Pengelolaan Diri adalah suatu bentuk kegiatan yang terfokus pada perubahan tingkah laku. Dalam pelaksanaannya, program pelatihan strategi pengelolaan diri menerapkan teori behavior modification, yang diimplementasikan dalam tiga strategi, yaitu self-monitoring, stimulus control, dan self-reward(Cormier \& Cormier, 1987; Miltenberger, 2011).

Dalam pelatihan strategi self-monitoring, kedua peserta menentukan sebuah target perubahan perilaku, yaitu : mengurangi durasi waktu bermain game online mereka sehari-hari. Setelah itu, kedua peserta menentukan goal yang dapat dicapai, yaitu : target durasi waktu bermain game online, yan disepakati di setiap sesi latihan mandiri yang akan mereka lakukan. Dengan menentukan goal yang harus mereka capai di setiap sesi latihan mandiri dan menuliskannya dalam buku kerja peserta, hal ini memudahkan peserta untuk memantau durasi waktu bermain game online mereka, apakah sudah melewati target (goal) atau belum.Menentukan sebuah target perubahan perilaku dan menentukan goal setting yang dapat dicapai adalah salah satu prinsip utama dalam behavior modification.

Dalam pelatihan strategi stimulus control, prinsip behavior modification yang digunakan adalah adanya usaha untuk memodifikasi kejadian sebelumnya yang dapat mencegah individu mencapai goal-nya. Usaha ini dilakukan oleh peserta melalui diskusi bersama antar kedua peserta dan peneliti mengenai hal-hal apa saja yang dapat menghambat mereka dalam mencapai goal (berupa target durasi waktu bermain game online) dan alternatif cara yang dapat mereka lakukan untuk mengatasi hambatan tersebut. Hasil diskusi tersebut kemudian akan diaplikasikan oleh para peserta dalam kehidupan sehari-hari, melalui latihan mandiri.

Dalam pelatihan strategi self-reward, prinsip behavior modification yang digunakan adalah adanya usaha untuk membangun rencana untuk memberikan reward pada diri sendiri saat berhasil memenuhi "goal" sehari-hari dan rencana memberikan hukuman saat gagal. Dalam pelaksanaannya, penggunaan strategi self-reward tidak merencanakan pemberian hukuman saat peserta gagal memenuhi target waktu

\footnotetext{
${ }^{1}$ PridaHarkina Program Studi Psikologi FK Universitas Malahayati, Bandar Lampung. Email : prida@malahayati.ac.id

${ }^{2}$ Rismijati E. Koesma Fakultas Psikologi Universitas Padjadjaran Bandung. Email : ceu tetty@yahoo.com.sg

${ }^{3}$ EstiWungu Fakultas Psikologi Universitas Padjadjaran Bandung. Email : estiwungu@yahoo.com
} 
bermain game online. Strategi self-reward hanya menggunakan pemberian memberikan reward pada diri sendiri saat berhasil memenuhi target waktu bermain game online yang telah ditentukan. Hal ini dilakukan untuk membantu klien mengatur dan menguatkan tingkah laku mereka sesuai konsekuensi yang telah ditetapkan (Cormier \& Cormier, 1987; Miltenberger, 2011)

Dalam pembahasan teori operant conditioning, penggunaan reward dijadikan sebagai bentuk konsekuensi yang menyenangkan bagi individu, yang dapat memberikan penguatan terhadap terjadinya suatu tingkah laku. Efek dari stimulus yang menyenangkan atau tidak menyenangkan (reinforceri) ini disebut reinforcement. Pada pelatihan strategi pengelolaan diri dalam penelitian ini, reward yang didapatkan oleh kedua peserta jika berhasil memenuhi target waktu bermain game online (goal) mereka, ditentukan oleh mereka sendiri. Kedua peserta dan peneliti melakukan diskusi bersama, menemukan kegiatan atau hal apa yang dapat menjadi reward bagi kedua peserta jika mereka berhasil memenuhi target waktu bermain game online (goal) mereka (Calhoun dan Acocella, 1990).

Selain insightyang ditumbuhkan pada kedua peserta sehingga menumbuhkan kesadaran akan perlunya perubahan perilaku, yang dilatihkan dalam ketiga strategi dalam pelatihan strategi pengelolaan diri, salah satu prinsip yang juga membuat pelatihan strategi pengelolaan diri ini bisa berhasil dalam memfasilitasi perubahan perilaku dari kedua peserta sehingga dapat meningkat self control peserta dalam bermain game online adalah karena dalam pelaksanaanya, peserta sendiri menentukan setiap langkahnya. Maksudnya, dalam pelatihan ini, peserta sendiri yang menentukan berapa banyak waktu bermain game online yang akan dikurangi (dan membentuk target waktu bermain game online), berapa lama waktu latihan mandiri yang akan mereka lakukan, alternatif cara apa yang akan mereka lakukan dalam mengatasi hambatan yang datang, serta reward apa yang dirasakan tepat untuk diri mereka sendiri. Dengan menentukan sendiri, peserta pada dasarnya membentuk suatu kontrak (perjanjina) dengan diri mereka sendiri, atau yang disebut dengan "self-contracting". Dengan demikian, peserta akan membangun rasa tanggung jawab terhadap program pelatihan yang sudah mereka rancang sendiri.

Berdasarkan pada penjelasan di atas, dapat disimpulkan bahwa ada beberapa prinsip yang mendasari pelatihan strategi pengelolaan diri dalam penelitian ini dapat meningkatkan self-control bermain game online pada remaja dengan adiksi game online tingkat sedang. Pertama adalah adanya kesadaran dan kesiapan dari peserta untuk merubah perilaku bermain game online mereka selama ini, yang didapatkan melalui penumbuhan insight dari peserta. Lalu adanya komitmen peserta dalam menjalankan rencana program pelatihan.

Dalam program pelatihan sendiri, tiga strategi pengelolaan diri, yaitu self monitoring, stimulus control,serta self reward yang diajarkan terbukti dapat meningkatkan self control bermain game online pada kedua peserta, dengan meningkatkan setiap aspek dari self control, yaitu cognitive control, decisional control, dan behavior control.

\section{SIMPULAN DAN SARAN}

Berdasarkan hasil penelitian yang telah dilakukan, maka kesimpulan yang dapat diambil adalah:

(a) Pelatihan Strategi Pengelolaan Diri dapat meningkatkan self-control (kontrol diri) pada remaja dengan adiksi game online tingkat sedang, dengan meningkat setiap aspek dari self control, yaitu cognitive control, decisional control, dan behavior control; (b) Kesiapan dan kesediaan peserta untuk merubah perilaku mereka, serta komitmen terhadap program pelatihan merupakan faktor yang mendukung pelaksanaan pelatihan ini sehingga dapat meningkatkan self control peserta dalam bermain game online.

Penelitian ini merupakan penelitian awal pengembangan intervensi untuk remaja yang mengalami adiksi game online tingkat sedang melalui pelatihan pengelolaan diri. Agar penelitian nantinya dapat diuji kembali secara empirik dan dilakukan uji efektivitas untuk mendapatkan pelatihan strategi pengelolaan diri yang terbukti efektif dalam meningkatkan self-control bermain game online pada remaja, penelitian dapat kembali dilakukan pada subjek yang lebih banyak, yang sesuai dengan karakteristik penelitian.

\section{Daftar Pustaka}

Averill, J. R. (1973). Personal control over aversive stimuli and its relationship to stress. Psychological bulletin, 80(4), 286.

\footnotetext{
1 PridaHarkina Program Studi Psikologi FK Universitas Malahayati, Bandar Lampung. Email : prida@malahayati.ac.id

${ }^{2}$ Rismijati E. Koesma Fakultas Psikologi Universitas Padjadjaran Bandung. Email : ceu tetty@yahoo.com.sg

${ }^{3}$ EstiWungu Fakultas Psikologi Universitas Padjadjaran Bandung. Email : estiwungu@yahoo.com
} 
Calhoun, J. F., \& Acocella, J. R. (1990). Psikologi tentang penyesuaian dan hubungan kemanusiaan (edisi ketiga). Satmoko, RS (Penerjemah) New York: McGraw-Hill.

Cao, F., Linyan, S. U., \& Gao, X. (1991). Control study of group psychotherapy on middle school students with Internet overuse. Chinese Mental Health Journal, (05).

Chaplin, J. P. (2006). Kamus lengkap psikologi (terjemahan Kartini Kartono). Jakarta: PT Raja Grafindo Persada.

Charlton, J. P., \& Danforth, I. D. (2007). Distinguishing addiction and high engagement in the context of online game playing. Computers in human behavior, 23(3), 1531-1548.

Clark, N. L. (2006). Addiction and the structural characteristics of massively multiplayer online games (Doctoral dissertation, University of Hawaii at Manoa).

Corey, G. (2012). Theory and practice of group counseling (Eight Edition). USA: Brooks/Cole.

Cormier, W. H., Cormier, L. S., \& Dryden, W. (1987). Interviewing Strategies for Helpers: Fundamental Skills and Cognitive-Behavioral Interventions. Journal of Cognitive Psychotherapy, 1(3), 199-200.

Fife-Schaw, C. (2012). Introduction to quantitative research. Research Methods in Psychology, 17.

Freimuth, M. (2008). Addicted?: Recognizing Destructive Behaviors Before It's Too Late. Rowman \& Littlefield Publishers.

Goodman, A. (1990). Addiction: definition and implications. British journal of addiction, 85(11), 1403-1408.

Griffiths, M. (2002). Gambling and gaming addictions in adolescence. Oxford: Bps Blackwell.

Jones, S. (2003). Let the games begin: Gaming technology and entertainment among college students. Pew Internet and American Life Project.
Miltenberger, R. G. (2011). Behavior modification: Principles and procedures. Cengage Learning.

Ningtyas, S. D. Y. (2012). Hubungan antara self control dengan internet addiction pada mahasiswa. Educational Psychology Journal, 1(1).

O'Donoghue, T., \& Rabin, M. (1999). Addiction and self-control. Addiction: Entries and exits, 169206.

Sanditaria, W. (2012). Adiksi Bermain Game Online pada Anak Usia Sekolah di Warung Internet Penyedia Game Online Jatinangor Sumedang. Students e-Journal, 1(1), 32.

Sarafino, E. P. (2012). Applied behavior analysis: principles and procedures for modifying behavior. Hoboken, NJ: Wiley.

Taylor, T. L. (2009). Play between worlds: Exploring online game culture. Mit Press.

Todman, J. B., \& Dugard, P. (2001). Single-case and small-n experimental designs: A practical guide to randomization tests. Psychology Press.

West, R., \& Brown, J. (2013). Theory of addiction. John Wiley \& Sons.

Young, K. S. (2007). Cognitive behavior therapy with Internet addicts: treatment outcomes and implications. CyberPsychology \& Behavior, 10(5), 671-679.

\footnotetext{
${ }^{1}$ PridaHarkina Program Studi Psikologi FK Universitas Malahayati, Bandar Lampung. Email : prida@malahayati.ac.id

2 Rismijati E. Koesma Fakultas Psikologi Universitas Padjadjaran Bandung. Email : ceu tetty@yahoo.com.sg

${ }^{3}$ EstiWungu Fakultas Psikologi Universitas Padjadjaran Bandung. Email : estiwungu@yahoo.com
} 